\title{
ALGORITHM-BASED BIM MODEL ANALYSIS METHODOLOGY AT URBAN LEVEL
}

DOI: $10.18485 /$ arh_pt.2020.7.ch36

\begin{abstract}
- Olivér Rák
Breuer Marcell Doctoral School of Architecture, Department of Engineering Studies, Institute of Smart Technology and Engineering, Faculty of Engineering and Information Technology, University of Pécs, Office: B223, Boszorkány st. 2., 7624 Pécs, Hungary, oliver.rak@mik.pte.hu
\end{abstract}

\section{- Ágnes Borsos \\ Associate Professor, Interim Head of Department of Interior, Applied and Creative Design Institute of Architecture, Faculty of Engineering and Information Technology, University of Pécs, Office: B327, Boszorkány st. 2., 7624 Pécs, Hungary, agnesborsos@mik.pte.hu}

\begin{abstract}
- Péter Iványi
Full Professor, Interim Head of Department of Systems and Software Technologies, Faculty of Engineering and Information Technology, University of Pécs, Office: B140 Boszorkány st. 2., 7624 Pécs, Hungary, ivanyi.peter@mik.pte.hu
\end{abstract}

\section{ABSTRACT}

In this paper, we described the use of Building Information Modeling methods for urban analysis. This purpose has been usually established by Geographic Information Systems however the development of Computer-Aided Design software made it possible to analyse large areas or parts of cities with the help of BIM models. This study focuses on the assessment of prefabricated large-panel buildings in the garden city of Pécs, in Hungary. The goal was to determine a building selection method according to the integrity of the area. We took into consideration infrastructural facilities, spatial position of shops, bus stations, and educational institutions compared to the locations of selected buildings. This approach supported the determination of potential inherent in renovations. The research consisted of three main stages: BIM model production methods and procedures, use of algorithm-based workflows during data import and spatial analysis, and quantification and evaluation of generated information. Due to the high complexity of Architectural, Engineering, and Construction projects and new digitalized methods, the use of algorithms and BIM models has been the fastest growing part of the industry in the past few years. This combination can support logical examinations and calculations between $3 \mathrm{D}$ and $2 \mathrm{D}$ information. The generated final results derived from locations made it possible to evaluate prospective renovations. The presented methodologies can be used in the case of other types of buildings and can support the decisions during the delivery of assets.

KEYWORDS _ building information modelling, algorithms, urban analysis, location value, renovation

\section{INTRODUCTION}

Hungarian prime minister has made a pronouncement in 2017 containing that 10 storey large-panel buildings' top floor could be demolished to solve overheating issues (HVG 2017). The news has brought the dilemma of these buildings into public awareness. In Hungary, there about 510.000 apartments that were built between 1961 and 1992 by manufactured technologies (Dési 1996). 
The lifetime of the large-panel buildings is close to reach their estimated operating time (Dr. Birghoffer and Hikisch 1994; Orbán 1978). There are examples of refurbishments (Ghazi Wakili et al. 2018; Ligęza 2015; Osztroluczky and Csoknyai 2005) but those were just pilot projects and nobody has made an urban level analysis of these buildings yet. The presented methods take into account the location of buildings compared to infrastructure, educational institutions, grocery stores, and restaurants. The main thesis of this research is that the location of the buildings affects their renovation value so it makes sense to calculate.

Development of Information Technology (IT) and Building Information Modelling (BIM) made it possible to analyse spatial information of a city. A few articles present economy based location value calculations (Akogun 2013; Kolbe et al. n.d.) but our research uses non-statistical methodologies finding impact value. BIM models are usually used in building level which allows supporting operations during the lifecycle (Ham Namhyuk et al. 2018; Heaton et al. 2019; Lee et al. 2012) and the previous studies were focused on the Return on Investment (ROI) of using BIM technologies (Kim et al. 2017; Walasek and Barszcz 2017). The purpose of this paper is to give urban design and management support due to the values of the examined buildings.

Urban models are commonly prepared in Geographic Information Systems (GIS) due to a huge amount of stored data. These models contain information about the location and spatial position but not in the geometry rather than as attributes. In this study, we examined what advantages can be obtained using 3D BIM models. There are researches applying algorithms but those were focused on the efficiency of energy consumption and possibilities of better living area development (Natanian et al. 2019; Vartholomaios 2017).

Garden city of Pécs (Figure 1.) has been chosen for the study because we knew this area well and had a great amount of data available. Large-panel buildings of the garden city were modelled to develop methodologies. (The "large-panel building" nomination is used for this type of asset. German nomination is "Plattenbau" but some articles using "prefabricated buildings".)

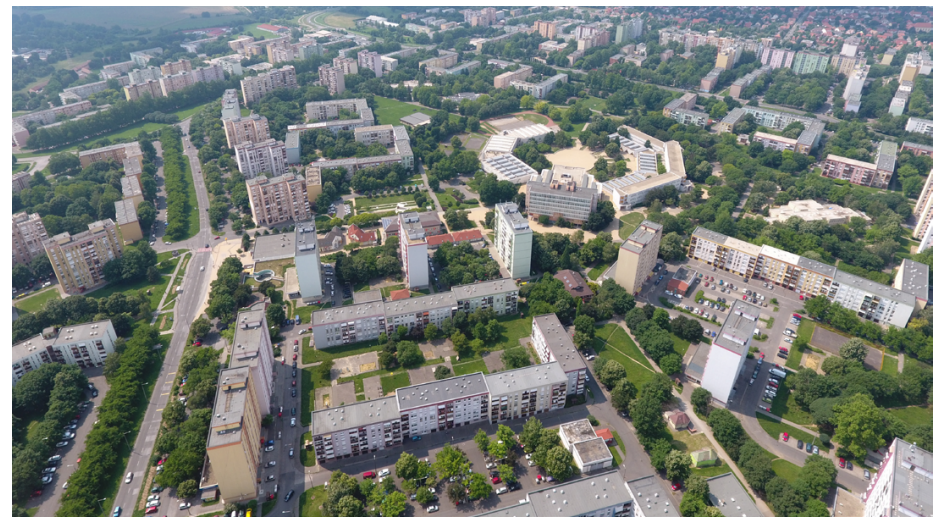

_ Figure 1. Photo of the examined area of Pécs, Hungary

\section{MATERIALS AND METHODS}

The BIM model was produced in Autodesk Revit 2020 platform because it can manage huge areas, lots of model elements, and has an algorithm module. The manual modelling method was used for the buildings' geometry and location. Data can be found in Google maps or Open Street Map were inaccurate to adopt automated workflow for modelling. Information on these websites were handled to position the elements but with corrections. Extra data were added into model elements from a study of Pécs garden city (Sipos 2015) such as building type and year of built parameters. Table 1 presents an element type list which contains the elements that were built in the virtual space. The 
number of elements is also shown in Table 1 to see how many geometries were utilized for the analysis. The examined area was about $6,8 \mathrm{~km} 2$ where all these model elements were placed.

_ Table 1: List of type and number of elements

\begin{tabular}{|c|c|c|c|c|c|c|c|}
\hline 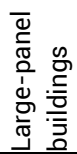 & $\begin{array}{l}\mathscr{0} \\
\frac{0}{0} \\
\frac{c}{\omega}\end{array}$ & $\begin{array}{l}\frac{0}{0} \\
0 \\
\frac{1}{0} \\
\infty\end{array}$ & 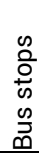 & 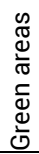 & $\begin{array}{l}\frac{0}{0} \\
\frac{5}{5} \\
\text { 음 } \\
\frac{\pi}{\frac{\pi}{\alpha}}\end{array}$ & 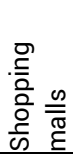 & 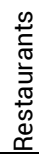 \\
\hline 840 & 28 & 7 & 64 & 31 & 59 & 2 & 17 \\
\hline
\end{tabular}

The main focus was on location analysis with the help of algorithms. There are studies about algorithm-based model examinations (Caetano and Leitão 2019; Feist et al. n.d.; Márk Máder et al. 2018) and solutions are connecting GIS and BIM models (Diakite and Zlatanova 2020; Wang et al. 2019; Zhang et al. 2020). However, algorithm-based BIM model analysis fields are not covered yet by the Architectural, Engineering, and Construction (AEC) industry.

Dynamo add-on was selected to carry out the analysis which enables application of logical connections for data examination. Due to the comparison of thousands element and accurate data requirement algorithms were necessary to be applied. Model elements were collated by the XYZ coordination of the center points which were calculated by the algorithms. In the case of larger areas such as green areas, all edges of virtual elements were examined in the calculation to find the closest points. Figure 2. presents the algorithm that was developed for the analysis. Different parts of the algorithm were used for different purposes as the colours highlight in Figure 2.

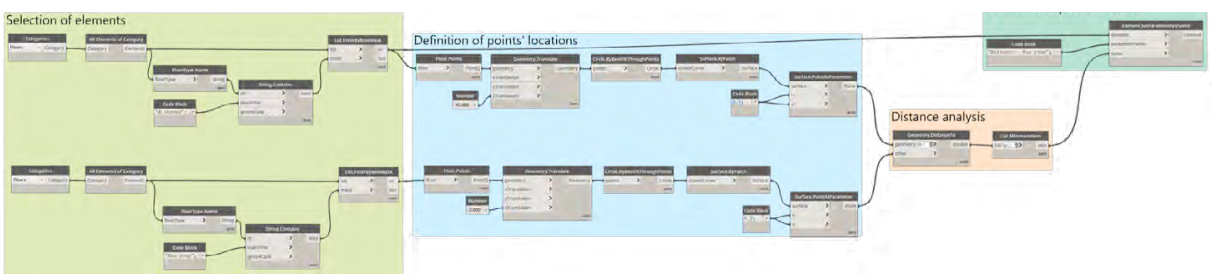

_ Figure 2. Screenshot of the developed algorithm from Autodesk Dynamo in the case of bus stops and 4 storey large-panel buildings analysis

"Selection of elements" group contained nodes for finding large-panel buildings (in this case " 4 storey") and "bus stop" elements. As it is shown in Figure 2. the point location definition was difficult because of the floor type elements. These elements geometry could have more than four points and circles were used to define them center points. Distance calculations were made by coordinates. There were two parts of the algorithm (one part for the large-panel buildings and one for the bus stops) which were compared to each other in the "Distance analysis" group. The results were sorted by the buildings and only the minimum values of the list were added to specific parameters of model elements. This process was adopted for all criteria except for green areas.

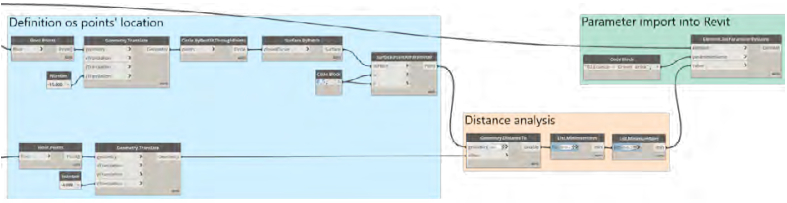

_ Figure 3. Screenshot of the developed algorithm from Autodesk Dynamo in the case of green areas and 4 storey large-panel buildings analysis 
As it is shown in Figure 3. the algorithm was modified to compare the locations of every point of elements to find the smallest distance between them.

A quantitative survey was also developed to define the relation and importance of criteria that were used in the research. It was filled by 320 respondents on an online form. It contained questions about apartment purchase preferences. Table 2 represents the questions and answer possibilities of the survey.

_ Table 2: Quantitative survey questions and answer possibilities

\begin{tabular}{|l|c|} 
Questions & \multicolumn{1}{c|}{ Possibilities of answers } \\
\hline What is your age? & \multicolumn{1}{c|}{ Number } \\
\hline Where do you live? & \multicolumn{1}{c|}{ "I live in Pécs", "I don't live in Pécs" } \\
\hline When have you bought last an asset?
\end{tabular}

This survey was developed to find weightings for the relevant factors in the calculation of the location values. Evaluation of the survey was made to calculate average numbers for the importance of distances from the selected asset. Analytical Hierarchy Process (AHP) (Saaty 1987, 1988, 1990) was applied to compare the importance of criteria. During the process, a comparison matrix was established where the differentiation was made by the survey results. There was a study where AHP was used for GIS data comparison (Al-shabeeb 2016) but not for building location analysis.

\section{RESULTS}

As a result, the BIM model analysis was made by the examined processes in previous sections. Distance parameters were calculated for all large-panel buildings ("4 storey" and " 10 storey") compared to every factor (Bus stop, Green area, Grocery store, Playground, Restaurant, School, Shopping mall). As figure 4. presents there were parameters made for distances in Revit and algorithms filled in the specific parameters according to the calculated results.

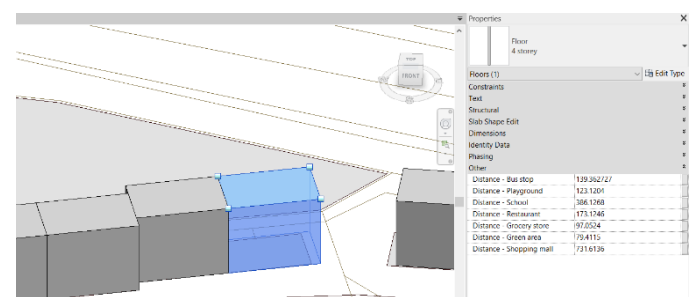

_ Figure 4. Screenshot of the parameters that were created in model elements in Autodesk Revit 2020 
After completing the calculation of distances, the questionnaire results were examined to define the weighting of the factors. AHP was used to establish it by pairwise comparison matrixes. As AHP requires criteria weights were calculated by a normalization method as it is shown in Table 4 . In the case of the AHP application, a review is needed to control calculations. Review steps: 1 st determine the Weight sums vector $(\mathrm{Ws})$ : Ws $=\mathrm{C} * \mathrm{~W} ; 2 \mathrm{nd}$ find the Consistency vector $(\mathrm{C}): \mathrm{C}=\mathrm{Ws} * 1 / \mathrm{W} ; 3$ rd determine the average $(\lambda)$; 4 th calculate the Consistency Index: $\mathrm{Cl}=(\lambda-n) /(n-1)$, where " $n$ " is the number of criteria; 5 th determine the Random Index (RI) - in the case of seven criteria the value is 1,32; 8 th determine the Consistency ratio ( $\mathrm{CR}$ ): $\mathrm{CR}=\mathrm{Cl} / \mathrm{RI}$ (Saaty 1987). In this case, the calculated $\mathrm{CR}$ value was 0,0946 which is less than 0,1 and it means the consistency of the calculation was correct.

_ Table 4: Normalized Criteria Comparison Matrix [C]

\begin{tabular}{|c|c|c|c|c|c|c|c|c|}
\hline Factors & $\frac{0}{\frac{0}{\infty}}$ & $\begin{array}{l}\overline{0} \\
\text { 응 }\end{array}$ & 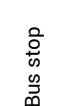 & 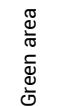 & 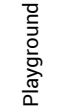 & 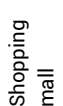 & 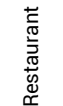 & Criteria weights \\
\hline Shop & 0,103 & 0,103 & 0,176 & 0,034 & 0,159 & 0,171 & 0,176 & 0,131802568 \\
\hline School & 0,103 & 0,103 & 0,176 & 0,034 & 0,159 & 0,171 & 0,176 & 0,131802568 \\
\hline Bus stop & 0,205 & 0,205 & 0,352 & 0,688 & 0,212 & 0,214 & 0,206 & 0,297565169 \\
\hline Green area & 0,513 & 0,513 & 0,088 & 0,172 & 0,372 & 0,3 & 0,235 & 0,31323602 \\
\hline Playground & 0,034 & 0,034 & 0,088 & 0,025 & 0,053 & 0,086 & 0,088 & 0,05827826 \\
\hline Shopping mall & 0,026 & 0,026 & 0,07 & 0,025 & 0,027 & 0,043 & 0,088 & 0,043408578 \\
\hline Restaurant & 0,017 & 0,017 & 0,05 & 0,022 & 0,018 & 0,014 & 0,029 & 0,023906839 \\
\hline
\end{tabular}

The use of criteria weights is presented in table 5 . in the section of appendixes. There were ten buildings randomly selected which distance parameter values were generated by the algorithms. The list was made as a schedule in Revit but the following calculations were established in Microsoft Excel. In the "calculated v." raw the used distances reciprocal values were calculated because of higher distance means worst location. Inverse parameters were multiplied by the related criteria weight. (E.g. Anikó street 2. - Bus stop: $(1 / 203.4705) * 0,2976=0,0015)$. The normalized values were computed according to "Calculated v." data. In the results column, the normalized values were assumed and translated to percentage which resulted in relative location values for the selected assets. As an example due to this method, the building at Aidinger János street 8 . had the highest rate $(16,44 \%)$ and that means its location was the best of all selected large-panel buildings compared by criteria.

\section{DISCUSSION AND CONCLUSION}

The results are well organized and stored in Revit model elements. Those could be more accurate if the land characteristic can be taken into account but in Pécs Garden city the area was nearly horizontal and modelling process would not worth it. According to the questionnaire and algorithm-based calculation results, the parameter comparison is well supported. But the requirements can be more specific by costumers, therefore criteria weights and used factors can be changed in the case of other circumstances. In general, the factors used in this research are relevant and as the survey presents there were no more criteria suggestion to use by the respondents.

As a conclusion, BIM models were adaptable to establish location analysis in urban level. Automatic calculations and imports of values were supported by algorithms that reduced the time it takes to do. According to the study results the location values can be calculated and it provided relevant information for a comprehensive refurbishment project. The applied and developed methodologies can be used for analysis of other types of buildings or in the case of more specific criteria, too. This development can be profitable for real estate or property managers to have relevant information on the locations not only derived from the prices. 
This study was the first step of a more comprehensive analysis. This research is going to be continued to determine data for refurbishment value in the case of Hungarian large-panel buildings according to the locations, conditions and renovation possibilities.

\section{REFERENCES}

_ Akogun, T. (2013). "IMPACT OF LOCATION ON PROPERTY VALUE AND BUSINESS DEVELOPMENT IN ILORIN METROPOLIS, NIGERIA." 5(10), 2735-2738.

_ Al-shabeeb, A. R. (2016). "The Use of AHP within GIS in Selecting Potential Sites for Water Harvesting Sites in the Azraq Basin-Jordan." Journal of Geographic Information System, 08(01), 73-88.

_ Caetano, I., and Leitão, A. (2019). "Integration of an algorithmic BIM approach in a traditional architecture studio." Journal of Computational Design and Engineering, 6(3), 327-336.

- Dési, A. (1996). Panelkalauz. Építésügyi Tájékoztató Központ.

_ Diakite, A. A., and Zlatanova, S. (2020). "Automatic geo-referencing of BIM in GIS environments using building footprints." Computers, Environment and Urban Systems, 80.

_ Dr. Birghoffer, P., and Hikisch, L. (1994). A panelos lakóépületek felújítása. Múszaki Könyvkiadó, Budapest.

_ Feist, S., Barreto, G., Ferreira, B., and Leitão, A. (n.d.). "PORTABLE GENERATIVE DESIGN FOR BUILDING INFORMATION MODELLING." 147-156.

_ Ghazi Wakili, K., Dworatzyk, C., Sanner, M., Sengespeick, A., Paronen, M., and Stahl, T. (2018). "Energy efficient retrofit of a prefabricated concrete panel building (Plattenbau) in Berlin by applying an aerogel based rendering to its façades." Energy and Buildings, 165, 293-300.

_ Ham Namhyuk, Moon Sungkon, Kim Ju-Hyung, and Kim Jae-Jun. (2018). "Economic Analysis of Design Errors in BIM-Based High-Rise Construction Projects: Case Study of Haeundae L Project." Journal of Construction Engineering and Management, 144(6), 05018006.

_- Heaton, J., Parlikad, A. K., and Schooling, J. (2019). "Design and development of BIM models to support operations and maintenance." Computers in Industry, 111, 172-186.

_ HVG. (2017). "Vissza lehet bontani a paneleket, de hol laknak majd utána az emberek?" hvg.hu, Digital newspaper, <https://hvg.hu/gazdasag/20170530_Vissza_lehet_bontani_a_paneleket_de_mi_lesz_utana> (Mar. 5, 2020).

_ Kim, S., Chin, S., Han, J., and Choi, C.-H. (2017). "Measurement of Construction BIM Value Based on a Case Study of a Large-Scale Building Project." Journal of Management in Engineering, 33(6), 05017005.

_ Kolbe, J., Schulz, R., Wersing, M., and Werwatz, A. (n.d.). "Location, location, location: Extracting location value from house prices."

_ Lee, G., Park, H. K., and Won, J. (2012). "D3 City project - Economic impact of BIM-assisted design validation." Automation in Construction, Planning Future Cities-Selected papers from the 2010 eCAADe Conference, 22, 577-586.

_ Ligęza, W. (2015). "Renovation of Large-Panel Buildings in Context of Urban Renewal/ Remonty Budynków Wielkopłytowych, Jako Element Rewitalizacji Miast." Civil And Environmental Engineering Reports, 17(2), 83-95.

- Márk Máder, P., Rák, O., and Háber, I. E. (2018). "Contemporary architecture based on algorithms." Pollack Periodica, 13(3), 53-60.

- Natanian, J., Aleksandrowicz, O., and Auer, T. (2019). "A parametric approach to optimizing urban form, energy balance and environmental quality: The case of Mediterranean districts." Applied Energy, 254, 113637.

_ Orbán, S. (1978). Építmények élettartamának tervezése. Mũszaki Könyvkiadó, Budapest.

_ Osztroluczky, M., and Csoknyai, T. (2005). "Solanova projekt - környezetbarát energiatudatos panelépület felújítási mintaprojekt Dunaújvárosban." Építés spektrum.

- Saaty, R. W. (1987). "The analytic hierarchy process-what it is and how it is used." Mathematical Modelling, 9(3-5), 161-176. 
- Saaty, T. L. (1988). "What is the Analytic Hierarchy Process?" Mathematical Models for Decision Support, G. Mitra, H. J. Greenberg, F. A. Lootsma, M. J. Rijkaert, and H. J. Zimmermann, eds., Springer Berlin Heidelberg, Berlin, Heidelberg, 109-121.

- Saaty, T. L. (1990). "How to make a decision: The analytic hierarchy process." European Journal of Operational Research, 48(1), 9-26.

- Sipos, B. (2015). Pécs-Kertváros, Egy új városrész kiépülése 1972-tol napjainkig. PTE BTK Kari Tudományos Diákköri Tanácsa, Pécs.

- Vartholomaios, A. (2017). "A parametric sensitivity analysis of the influence of urban form on domestic energy consumption for heating and cooling in a Mediterranean city." Sustainable Cities and Society, 28, 135-145.

- Walasek, D., and Barszcz, A. (2017). "Analysis of the Adoption Rate of Building Information Modeling [BIM] and its Return on Investment [ROI]." Procedia Engineering, Modern Building Materials, Structures and Techniques, 172, 1227-1234.

- Wang, H., Pan, Y., and Luo, X. (2019). "Integration of BIM and GIS in sustainable built environment: A review and bibliometric analysis." Automation in Construction, 103, 41-52.

_ Zhang, S., Hou, D., Wang, C., Pan, F., and Yan, L. (2020). "Integrating and managing BIM in 3D webbased GIS for hydraulic and hydropower engineering projects." Automation in Construction, 112, 103114.

\section{APPENDIXES}

_ Table 5. Calculation and final results of the comparison of ten randomly selected buildings

\begin{tabular}{|c|c|c|c|c|c|c|c|c|c|}
\hline 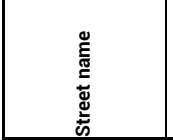 & 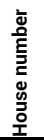 & 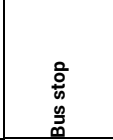 & 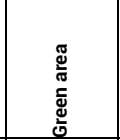 & 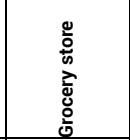 & 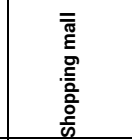 & 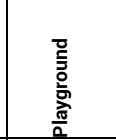 & 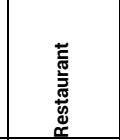 & $\begin{array}{l}\overline{0} \\
\stackrel{\circ}{0} \\
\text { ch }\end{array}$ & 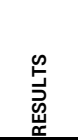 \\
\hline Criteria weights & & 0,2976 & 0,3132 & 0,1318 & 0,0434 & 0,0583 & 0,0239 & 0,1318 & \multirow[b]{4}{*}{$11,64 \%$} \\
\hline Anikó & 2. & 203,4705 & 216,0000 & 89,0000 & 760,0000 & 124,0000 & \multicolumn{2}{|c|}{$\begin{array}{lll}0 & 185,0000 & 74,0000 \\
\end{array}$} & \\
\hline Calculated v. & & 0,0015 & 0,0015 & 0,0015 & 0,0001 & 0,0005 & 0,0001 & 0,0018 & \\
\hline Normalized v. & & 0,0694 & 0,0454 & 0,1718 & 0,1156 & 0,0536 & 0,0955 & 0,2631 & \\
\hline Dóra & 8. & 126,7471 & 154,0000 & 159,0000 & 642,0000 & 54,0000 & 197,0000 & 177,0000 & \multirow[b]{3}{*}{$10,44 \%$} \\
\hline Calculated v. & & 0,0023 & 0,0020 & 0,0008 & 0,0001 & 0,0011 & 0,0001 & 0,0007 & \\
\hline Normalized v. & & 0,1114 & 0,0637 & 0,0961 & 0,1368 & 0,1232 & 0,0897 & 0,1100 & \\
\hline Enyezd & 24. & 108,5934 & $4 \quad 100,0000$ & 90,0000 & 1061,0000 & 128,0000 & 140,0000 & 350,0000 & \multirow[b]{3}{*}{$10,21 \%$} \\
\hline Calculated v. & & 0,0027 & 0,0031 & 0,0015 & 0,0000 & 0,0005 & 0,0002 & 0,0004 & \\
\hline Normalized v. & & 0,1301 & 0,0981 & 0,1699 & 0,0828 & 0,0520 & 0,1263 & 0,0556 & \\
\hline Aidinger János & 8. & 130,6471 & 26,0000 & 102,0000 & 922,0000 & 24,0000 & 210,0000 & 332,0000 & \multirow[b]{3}{*}{$16,44 \%$} \\
\hline Calculated v. & & 0,0023 & 0,0120 & 0,0013 & 0,0000 & 0,0024 & 0,0001 & 0,0004 & \\
\hline Normalized v. & & 0,1081 & 0,3774 & 0,1499 & 0,0953 & 0,2772 & 0,0842 & 0,0586 & \\
\hline Enyezd & 13. & 138,9428 & 131,0000 & 246,0000 & 1106,0000 & 25,0000 & 300,0000 & 438,0000 & \multirow[b]{3}{*}{$9,82 \%$} \\
\hline Calculated v. & & 0,0021 & 0,0024 & 0,0005 & 0,0000 & 0,0023 & 0,0001 & 0,0003 & \\
\hline Normalized v. & & 0,1017 & 0,0749 & 0,0621 & 0,0794 & 0,2661 & 0,0589 & 0,0444 & \\
\hline Aidinger János & 39. & 170,5001 & 53,0000 & 158,0000 & 579,0000 & 143,0000 & 147,0000 & 411,0000 & \multirow[b]{3}{*}{$10,44 \%$} \\
\hline Calculated v. & & 0,0017 & 0,0059 & 0,0008 & 0,0001 & 0,0004 & 0,0002 & 0,0003 & \\
\hline Normalized v. & & 0,0828 & 0,1851 & 0,0968 & 0,1517 & 0,0465 & 0,1202 & 0,0474 & \\
\hline Csikor Kálmán & 31. & 259,2919 & 679,0000 & 567,0000 & 907,0000 & 198,0000 & 252,0000 & 1216,0000 & \multirow{4}{*}{$4,46 \%$} \\
\hline Calculated v. & & 0,0011 & 0,0005 & 0,0002 & 0,0000 & 0,0003 & 0,0001 & 0,0001 & \\
\hline Normalized v. & & 0,0545 & 0,0145 & 0,0270 & 0,0969 & 0,0336 & 0,0701 & 0,0160 & \\
\hline Berek & 7. & 178,4722 & 173,0000 & 97,0000 & 867,0000 & 124,0000 & 62,0000 & 56,0000 & \\
\hline
\end{tabular}




\begin{tabular}{|c|c|c|c|c|c|c|c|c|}
\hline Calculated v. & 0,0017 & 0,0018 & 0,0014 & 0,0001 & 0,0005 & 0,0004 & 0,0024 & \multirow[b]{2}{*}{$15,45 \%$} \\
\hline Normalized v. & 0,0791 & 0,0567 & 0,1576 & 0,1013 & 0,0536 & 0,2851 & 0,3477 & \\
\hline Csipke 3. & 95,4689 & 229,0000 & 1087,0000 & 1403,0000 & 136,0000 & 937,0000 & 882,0000 & \\
\hline Calculated v. & 0,0031 & 0,0014 & 0,0001 & 0,0000 & 0,0004 & 0,0000 & 0,0001 & \\
\hline Normalized v. & 0,1480 & 0,0429 & 0,0141 & 0,0626 & 0,0489 & 0,0189 & 0,0221 & $5,10 \%$ \\
\hline Boros István 1. & 122,9586 & 238,0000 & 279,0000 & 1134,0000 & 147,0000 & 346,0000 & 555,0000 & \\
\hline Calculated v. & 0,0024 & 0,0013 & 0,0005 & 0,0000 & 0,0004 & 0,0001 & 0,0002 & \\
\hline Normalized v. & 0,1149 & 0,0412 & 0,0548 & 0,0775 & 0,0453 & 0,0511 & 0,0351 & $6,00 \%$ \\
\hline
\end{tabular}

